\title{
Interleukin 6 as inflammatory marker and insulin resistance in obese Kuwaiti adolescents
}

\author{
Ibrahim El-Byoumy* \\ Public Health and Community Medicine - Tanta Faculty of Medicine, Egypt
}

\begin{abstract}
Background: Obesity has become a rapidly growing epidemic in both adults and children. The obesity occurs due to the increased mass of adipose tissue that secrets cytokines like interleukin 6 and production of Tumour Necrotic Factor- $\alpha$ (TNF- $\alpha$ ), and the condition in associated with insulin resistance.

Objective: To determine the insulin resistance state and interleukin 6 levels in the serum of obese Kuwait adolescents 13-18 years, and also investigate if there is significant association between interleukin 6 and insulin resistance.

Methods: The study in cross-sectional study conducted from March 2015 to June 2015 in Kuwait. Obese children were selected randomly in Farwnaiyah Primary health care center and was named the study group compared with 42 adolescents with normal Body Mass Index (BMI) i.e. the control group. The adolescents age 13-18 years, where specimens for fasting blood glucose, fasting insulin levels, Tumor Necrotic Factor- $\alpha$ (TNF- $\alpha$ ), Interleukin 6 levels were estimated by Enzyme Immunoassay (EIA). Insulin resistance was estimated by Homeostatic Model Assessment of Insulin Resistance i.e. Homa-IR level above 3.4 was chosen as a cut-off point to define IR.
\end{abstract}

Results: There was high levels of interleukin 6 reported among the obese adolescents, also high levels of fasting insulin and insulin resistance. Using linear regression, there was no significant association between IL-6 and the occurrence of insulin resistance $(\mathrm{P}=0-318)$. The log regression coefficient value of IL-6 was negative (b= $-415)$.

Conclusion: High interleukin levels were reported among the obese adolescents, also Insulin resistance state. But there was negative correlation between IL-6 levels and the occurrence of insulin resistance in obese Kuwaiti adolescents.

\section{Introduction}

Childhood obesity has become an ever-increasing problem with increased risk of morbidity and mortality and there is increased evidence that obesity in childhood is responsible for development of adult type 2 diabetes mellitus, metabolic syndrome and the cardiovascular diseases [1,2].

Adipose tissue is currently considered to be hormonally active and take a part in the control of metabolism. Adipose tissue is a rich source of many immune related mediators that are involved in the inflammatory response, it produces proinflammatory cytokines, such as interleukin 6 (IL-6) and tumour necrosis factor- $\alpha$ (TNF- $\alpha$ ) and complement factors, the hepatic synthesis of acute phase inflammatory proteins as C-reactive Protein (CRP), complement factors C3 and C4 and ceruloplasmin are under the control of these proinflammatory cytokines, and therefore, adipose tissue is a noteworthy agent of the high circulating concentrations of both cytokines and proteins [3].

It has been estimated that $25 \%$ of circulating interleukin 6 is released by human subcutaneous adipose tissue. Many research studies have showed that some markers of inflammation are increased in obesity and type 2 diabetes mellitus, so that activation of immune system for long term duration in associated in the development of insulin resistance and diabetes mellitus [4].

Many research studies in adults showed that increased levels of interleukin 6 (IL-6) and Tumor Necrosis Factor- $\alpha$ (TNF- $\alpha$ ) is associated with a state of sub-clinical inflammation and associated with development of insulin resistance (IR), metabolic syndrome (MS), atherogenesis and non-alcoholic fatty liver disease (NAFLD) $[5,6]$.

\section{Subjects and methods}

\section{Participants}

A total 61 obese adolescents aged 13-18 years included in the study, selected randomly from the outpatient clinic in the Farwaniyh primary health care center in Kuwait obesity was defined as body mass index (BMI). Percentile $95^{\text {th }}$ for child's age and gender according to the centers for Disease Control (CDC) 2000 references [7]. This group was named obese group and another 42 adolescents were included in this study with normal BMI, and this group was named the healthy group conducted from March 2015 to June 2015.

First, measuring of blood pressure was done for both groups, using auscultator $y$ method by the sphygmomanometer. The weight was measured to the nearest $0.1 \mathrm{~kg}$ in adolescents standing barefoot in light clothing. Height was measured to the nearest $1 \mathrm{~mm}$ with adolescents standing in upright position and the head in the Frankfurt plane, measurement was done using a portable stadiometer.

Correspondence to: Ibrahim El-Byoumy, Public Health and Community Medicine - Tanta Faculty of Medicine, Egypt, E-mail: Ibrahim.elbayoumy@ med.tanta.edu.eg

Key words: adolescents, obesity, insulin resistance, interleukin 6

Received: May 02, 2017; Accepted: June 01, 2017; Published: June 05, 2017 
Body Mass Index (BMI) was calculated by dividing weight in $\mathrm{kg} / \mathrm{m}^{2}$ (in meters). Waist circumference (WC) was measured using inelastic tape horizontally midway between the lowest rib margin and the iliac crest, after gentle expiration. The hip circumference was measured at the point yielding the maximum circumference over the buttocks, and the tape was held in the horizontal plane and waist-hip ratio was calculated.

A sample of venous blood was obtained after a 12-hour fasting in order to determine concentrations of insulin by chemiluminescene immunoassay (Access Beckman Coulter Instruments, Brea California), glucose and plasma lipids by an enzymatic method, and high density lipoprotein cholesterol (HDL-C) assayed by addition of magnesium ions (Syncron CX Beckman Instruments, Brea California). Low density liporprotion cholesterol (LDL-C) levels were estimated using Friedewald formula, modified by De Long [8].

Insulin resistance was defined as a clinical condition with potential decline of both endogenous and exogenous insulin to enhance glucose uptake and glucose utilization by the cells of the body. In this study insulin resistance is expressed in homeostatic model of assessment of insulin resistance (HOMA-IR), which was calculated using the following equation: [(fasting glucose $(\mathrm{mg} / \mathrm{dl})$ (fasting insulin $(\mu \mathrm{u} /$ $\mathrm{ml}) / 405)][9]$.

A HOMA-IR value of 3.4 was chosen as the cut-off point to define IR, as it has been suggested that beyond this value, which corresponds to the $90^{\text {th }}$ percentile of a population of healthy, IR becomes a cardiovascular risk factor [10].

Interleuckin- 6 was measured in the serum by enzyme immunoassay (EIA). The assay was performed in duplicate using kits provided by Immunotech (Marseille, France). The minimum concentration detected was $3 \mathrm{pg} / \mathrm{ml}$ [11]. TNF- a was estimated by the same method.

\section{Results and discussion}

This study involved 61 males in the obese adolescents group and 42 males in the control healthy group with mean of age $14.8 \pm 1.3$ years in obese group and $14.6 \pm 1.5$ years in the control healthy group.

High fasting insulin levels were observed in the obese adolescents $26.1 \pm 15.9 \mu \mathrm{u} / \mathrm{ml}$ vs $8.9 \pm 4.3 \mu \mathrm{u} / \mathrm{ml}$ in the control healthy group with presence of insulin resistance in the obese adolescents as HOMA-IR = $6.3 \pm 4.2$ and the cut-off point was 3.4 , so that obesity appears to disrupt the ability of insulin to affect glucose uptake and metabolism in tissues sensitive to insulin (known as insulin resistance).

The results coincide with Serrano et al. 2010 [12]. They observed that obese and overweight adolescents were having 4.5-fold more likely to have alterations in HOMA-IR index and having a higher value with higher percentage of body fat (Tables 1 and 2).

Also Mieldazis et al. [13] were investigating the association between BMI, HOMA-IR and insulin levels in obese children, and concluded that there is strong association between hyperinsulinemia and obesity and that the higher the BMI, the higher HOMA-IR. Our results coincide also with Lavrador et al. [14], they observed that higher degrees of obesity had higher frequencies of alterations in blood glucose, HOMAIR, triglycerides, demonstrating that the degree of obesity influences the onset of clinical and metabolic alternations (Table 3).

Interleukin 6 is a circulating multifunctional cytokine with various functions such as inflammation, host defense, and tissue injury. It is produced by many cell types and tissues, including immune cells, fibroblasts, endothelial cells, skeletal muscles, and adipose tissue. Adipose cells contribute 15 to $30 \%$ of circulating IL- 6 levels in the
Table 1. Comparison between obese adolescents and healthy adolescents i.e control group.

\begin{tabular}{|c|c|c|c|}
\hline & Obese adolescents & Healthy controls & P Value \\
\hline Adolescents $(\mathrm{n})$ & $61(30$ female $)$ & $42(22$ female $)$ & \\
\hline $\begin{array}{c}\text { Age (years) } \\
\text { Means SD }\end{array}$ & $14.8 \pm 1.3$ & $14.6 \pm 1.5$ & 0.148 \\
\hline Weight $(\mathrm{KG})$ & $72.1 \pm 18.7$ & $35.9 \pm 13.1$ & $<0.001$ \\
\hline BMI $\left(\mathrm{kg} / \mathrm{m}^{2}\right)$ & $31.8 \pm 3.9$ & $19.4 \pm 2.8$ & $<0.001$ \\
\hline WC(cm) & $105.2 \pm 11.9$ & $64 \pm 8.9$ & $<0.001$ \\
\hline Waist to hip ratio & $112.2 \pm 10.4$ & $0.81 \pm 0.05$ & $<0.001$ \\
\hline $\begin{array}{c}\text { Fasting Glucose } \\
(\mathrm{mg} / \mathrm{dl})\end{array}$ & $101.1 \pm 10.3$ & $83.1 \pm 6.8$ & $<0.001$ \\
\hline $\begin{array}{c}\text { Fasting Insulin } \\
(\mu \mathrm{u} / \mathrm{ml})\end{array}$ & $26.1 \pm 15.9$ & $8.9 \pm 4.3$ & $<0.001$ \\
\hline HOMA-IR & $6.3 \pm 4.2$ & $1.7 \pm 0.9$ & $<0.001$ \\
\hline SBP $(\mathrm{mmHg})$ & $100 \pm 5.2$ & $97.5 \pm 10$ & 0.474 \\
\hline DBP $(\mathrm{mmHg})$ & $65 \pm 7.1$ & $65.6 \pm 6.8$ & 0.798 \\
\hline IL-6 $(\mathrm{Pg} / \mathrm{ml})$ & $4.6 \pm 1.9$ & $1.1 \pm 0.5$ & $<0.001$ \\
\hline TNFX $(\mathrm{Pg} / \mathrm{ml})$ & $2.2 \pm 1.3$ & $2.0 \pm 0.6$ & 0.805 \\
\hline
\end{tabular}

Table 2. Lipids Profile among the study and control groups.

\begin{tabular}{|c|c|c|c|}
\hline & Obese adolescents & Healthy controls & P Value \\
\hline $\begin{array}{c}\text { Total Cholesterol } \\
(\mathrm{mmol} / \mathrm{l})\end{array}$ & $4.27 \pm 0.72$ & $4.08 \pm 0.8$ & 0.432 \\
\hline $\begin{array}{c}\mathrm{HDL}-\mathrm{Cholesterol} \\
(\mathrm{mmol} / \mathrm{l})\end{array}$ & $1.29 \pm 0.14$ & $1.4 \pm 0.16$ & 0.517 \\
\hline $\begin{array}{c}\text { LDL-Cholesterol } \\
(\mathrm{mmol} / \mathrm{l})\end{array}$ & $2.7 \pm 0.9$ & $2.13 \pm 0.7$ & 0.521 \\
\hline $\begin{array}{c}\text { Triglycerides } \\
(\mathrm{mmol} / \mathrm{l})\end{array}$ & $0.87 \pm 0.34$ & $0.77 \pm 1.05$ & 0.648 \\
\hline
\end{tabular}

Table 3. Correlation between interleukin- 6 with insulin resistance incidence in obese adolescents.

\begin{tabular}{|c|c|c|}
\hline Model & Regression coefficient & P Value \\
\hline Constant & -0.762 & 0.227 \\
\hline IL-6 & -0.415 & 0.318 \\
\hline
\end{tabular}

absence of acute inflammation [15]. In this study, high levels of IL-6 were recorded among the obese adolescents $4.6 \pm 1.9 \mathrm{pg} / \mathrm{ml}$. This result coincides with Fried et al. [16], they reported that Interleukin 6 production is significantly enhanced by adipose tissue in obesity (Figure 1).

The adverse effects of increase IL- 6 in obesity include two major adverse effects as insulin resistance and increased risk for cardiovascular complications. Circulating IL- 6 was found to be associated with insulin resistance in healthy men, in obese women and in cancer patients [17-19].

Logistic regression analysis, revealed no significant association between IL-6 levels and the incidence of insulin resistance in obese adolescents $(\mathrm{P}=0.318)$. Log regression coefficient value of IL-6 was negative $(b=-0.415)$, showing an inverse relationship between the insulin resistance incidence and levels of IL-6 in obese adolescents. These results did not coincide with Yaste et al. [14], they reported that there is a positive correlation between plasma level of IL-6 levels and insulin resistance in obese adults and children.

The higher levels of interleukin 6 in obese children are considered to be a predictor of type 2 diabetes and future myocardial infarction $[20,21]$ where in 20 obese adolescents, high levels of creative protein and IL- 6 were found compared with the control group, they were obese and having fatty liver disease.

\section{Conclusion}

In conclusion, obese adolescents in our study had significantly raised interleukin-6 (IL-6) compared to normal weight children, reinforcing the evidence that subclinical inflammation is already 


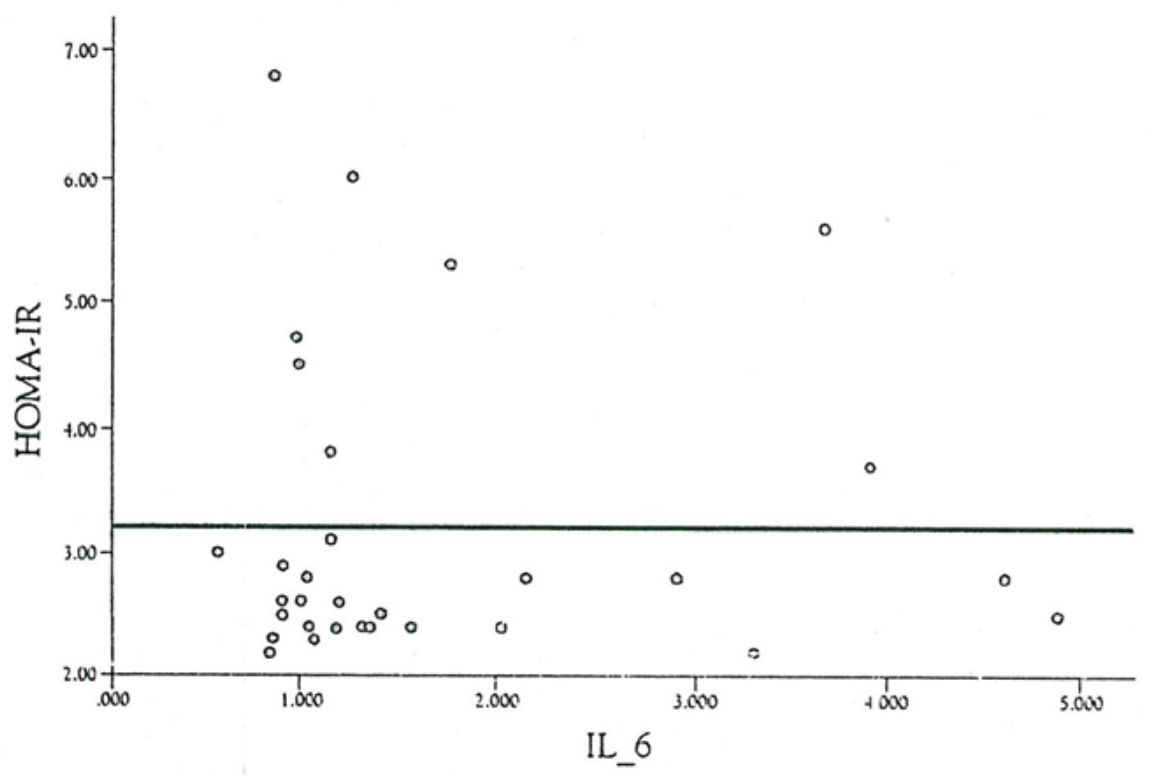

Figure 1. Correlation between IL-6 and HOMA-IR in obese adolescents.

present in childhood obesity, so that obesity may lead to development of metabolic syndrome and insulin resistance, so that we should do our efforts to prevent obesity through:

1. Healthy lifestyle habits, including healthy eating and increase physical activity.

2. The dietary and physical activity behaviors of children and adolescents are influenced by many factors and sectors of society, including families, communities, schools, child care settings, medical care providers, government, the media, and the food and beverage industries and entertainment industries.

3. Schools play a critical role by establishing a safe and supportive environment with policies and practices that support healthy behaviors. Schools also provide opportunities for children to learn about and practice healthy eating and physical activity behaviors.

\section{References}

1. Weiss R, Dziura J, Burgert TS, Tamborlane WV, Taksali SE, et al. (2004) Obesity and the metabolic syndrome in children and adolescents. N Engl J Med 350: 2362-2374. [Crossref]

2. Viggiano D, De Filippo G, Rendina D, Fasolino A, D'Alessio N, et al. Screening of metabolic syndrome in obese children: a primary care concern. J Pediatr Gastroenterol Nut. 2009; 49: 329-334.

3. Trayhurn P, Wood IS (2004) Adipokines: Inflammation and pleiotropic role of white adipose tissue. BR J Nut 92: 347-55.

4. Yeste D, Vendrell J, Tomasini R, Broch M, Gussinyé M, et al. (2007) Interleukin-6 in obese children and adolescents with and without glucose intolerance. Diabetes Care 30: 1892-1894. [Crossref]

5. Arner P (2005) Insulin resistance in type 2 diabetes -- role of the adipokines. Curr Mol Med 5: 333-339. [Crossref]

6. Fisman Ez, Tenenbaum A (2010) The ubiquitous interleukein-6: a time for reappraisal. Cardiovascular Diabetol 9: 62.

7. Kuczmarski RJ, Ogden CL, Guo SS, Grummer-Strawn LM, Flegal KM, et al. (2002) 2000 CDC growth charts for United States: methods and development. National Center for Health Statistics. Vital Health Stat 11: 1-190.

8. De Long DM, De Long ER, Wood PD, Lippel K (1986) A comparison of methods for estimation of plasma low- and very low-density lipoprotein cholesterol. The lipid research clinic prevalence study. JAMA 256: 2372-2377.
9. Keskin M, Kurtoglu S, Kendirci M, Atabek ME, Yazici (2005) Homeostasis model assessment in more reliable than the fasting glucose/ insulin ratio and quantitative insulin sensitivity check index for assessing insulin resistance among obese children and adolescents. Pediatrics 115: e500-503.

10. Lebovitz He, Banerji MA (2005) Point Visceral adiposity is casually related to insulin resistance. Diabetics Care 28(a): 2322-2325.

11. Biffl WL, Moore EE, Moore FA, Peterson VM (1996) Interleukin-6 in the injured patient Marker of injury or mediator of inflammation? Ann Surg 224: 647-664. [Crossref]

12. Serrano HM, Carvalho GQ, Pereira PD, Peluzio Mdo C, Franceschini Sdo C, et al (2010) Body Composition, biochemical and clinical changes of adolescents with excessive adiposity. Arq Bras Cordial 95: 464-472.

13. Mieldazis SF, Azzalis LA, Junqueira VB, Souza FI, Sarni RO, et al. (2010) Hyperinsulinism assessment in a sample of prepubescent children. J Pediatr 86: 245-249.

14. Lavrador MS, Abbes PT, Escrivao MA, Taddei JA (2011) Cardiovascular risks in adolescents with different degrees of obesity. Arq Bras Cardiol 96: 205-211.

15. Mohamed-Ali V, Goodrick S, Rawesh A, Katz DR, Miles JM, et al. (1997) Subcutaneous adipose tissue releases interleukin-6, but not tumor necrosis factor-alpha, in vivo. J Clin Endocrinol Metab 82: 4196-4200. [Crossref]

16. Fried SK, Bunkin DA, Greenberg AS (1998) Omental and subcutaneous adipose tissues of obese subject's release interleukin-6: depot difference and regulation by glucocorticoid. J Clin Endocrinal Metab 83: 847-850.

17. Fernandez-Real JM, Vayreda M, Richart C, Gutierrez C, Broch M, et al. (2001) Circulating interleukin 6 levels, blood pressure and insulin sensitivity in apparently healthy men and women. J Clin Endocrinol Metab 86: 1154-1159.

18. Kern PA, Ranganthan S, Lic, Wood L, Ranganathan G (2001) Adipose tissue tumor necrosis factor and interleukin-6 expression in human obesity and insulin resistance. Am J Physiol 280: 745-751.

19. Vozarova B, Weyer C, Hanson K, Tataranni PA, Bogradus C, et al. (2001) Circulating Interleukin 6 in relation to adiposity, insulin action, and insulin secretion. Obes Res 9: 414-417.

20. Ridker PM, Rifai N, Stampter MJ, Hennekens CH (2000) Plasma concentration of interleukin- 6 and the risk of future myocardial infraction among apparently healthy men. Circulation 101: 1767-1772.

21. Angin Y, Kuralay F, Arslan N (2009) Evolution of metabolic, antioxidant and oxidant systemic determinants in non-alcoholic fatty liver disease relevant to pediatric obesity In: Sahin MF, Zefirov NS, editors, $1^{\text {st }}$ Turkish-Russian Joint Meeting on Organic and Medicinal Chemistry, Turkey, pp: 64

Copyright: (C2017 El-Byoumy I. This is an open-access article distributed under the terms of the Creative Commons Attribution License, which permits unrestricted use, distribution, and reproduction in any medium, provided the original author and source are credited. 